\title{
IL16 Gene Product
}

National Cancer Institute

\section{Source}

National Cancer Institute. IL16 Gene Product. NCI Thesaurus. Code C116764.

A protein encoded by the IL16 gene. 